\title{
Studies on the composition of food
}

\section{2.* Comparison of the nutrient content of bread made conventionally and by the Chorleywood Bread Process}

\author{
By N. CHAMBERLAIN, T. H. COLLINS ANd G. A. H. ELTON
}

British Baking Industries Research Association, Chorleywood, Herts.

AND DORO'THY F. HOLLINGSWORTH

Ministry of Agriculture, Fisheries and Food, London, SWI

AND D. B. LISLE

Ministry of Technology, Laboratory of the Government Chemist, London, $S E_{\mathrm{I}}$

\author{
AND P. R. PAYNE \\ Human Nutrition Research Unit, National Institute for Medical \\ Research, Mill Hill, London, $N W_{7}$
}

(Received I I January 1966-Accepted 4 March I966)

\begin{abstract}
I. The Chorleywood Bread Process is a new method of making bread in which the 2-4 h of bulk fermentation of the dough normal in breadmaking is replaced by a few minutes of intense mechanical agitation to a controlled degree in special high-speed mixers. It is now being used to make over $30 \%$ of British bread. 2. Bread was made in a commercial bakery from two white flours by the Chorleywood Bread Process and a conventional method. 3. Both the bread and flours were analysed for moisture, protein, ash, fat, carbohydrate (by difference), thiamine, nicotinic acid and ascorbic acid. 4. More bread was made by the two processes from two other flours in a pilot-scale bakery. These breads and flours were used to determine net protein utilization values. 5. It was concluded that bread made by the Chorleywood Process cannot be distinguished from conventional bread in its content of protein, fat, ash and nicotinic acid, and in protein quality as indicated by its net protein utilization value. This was true for two grades of flour. In these tests the contents of thiamine and moisture were slightly higher and of carbohydrate slightly lower in Chorleywood than in conventional bread. No ascorbic or dehydroascorbic acid could be detected in any of the bread.
\end{abstract}

There are now several processes operating in Britain and other countries that increase the speed of conversion of flour and other ingredients into bread. One of these is the Chorleywood Bread Process (CBP) which was introduced to the British baking industry in 1961 by the British Baking Industries Research Association; the first commercial plant began to operate in 1962 . Acceptance of the process has been, and continues to be, so rapid that by the middle of 1965 it was estimated (Chamberlain, Collins \& Elton, $1965 a$ ) that $25-30 \%$ of British bread was made in this way. In these circumstances it seemed desirable to determine whether the nutrient content of bread made by the new process differed in any major respect from conventional bread, especially as white bread provides in the average British diet about $14 \%$ of the calories, $17 \%$ of the protein, $14 \%$ of the calcium, $17 \%$ of the iron, $18 \%$ of the

* Paper no. I; Br. F. Nutr. (1966), 20, 675. 
thiamine and $15 \%$ of the nicotinic acid (Ministry of Agriculture, Fisheries and Food: National Food Survey Committee, 1965).

The CBP (Chamberlain, Collins \& Elton, 1962) is a method of making bread in which the process of bulk fermentation of the dough after mixing, which normally occupies a period of $2-4 \mathrm{~h}$ in British practice, is eliminated. Instead, the dough is mechanically developed in a special high-speed mixer by the expenditure of $5 \mathrm{Wh}$ energy per $\mathrm{lb}$ dough in a time of less than $5 \mathrm{~min}$. This quantity of energy is about five to eight times greater than that normally expended during conventional dough mixing and is applied over a shorter period of time, so that there is an appreciably greater rise in dough temperature during this step. In fact, there is usually a temperature rise of about $14^{\circ}$ above the mean temperature of the flour and water ingredients, and the temperature of the mixed dough is usually about $3-5^{\circ}$ above that of conventional doughs.

In conventional practice the bulk fermentation of the dough is followed by two periods of 'proof', in which individual dough pieces cut from the bulk dough are allowed to rest and expand at a constant temperature. In the CBP these proof periods are retained, though the first of them may be somewhat shorter than usual.

Other features of the CBP are the use of ascorbic acid as bread improver at a standard level of $0.0075 \%$ of flour, an increase in the normal yeast level by up to $100 \%$, the addition of extra water to compensate for the absence of dough softening and loss of flour solids which normally take place during fermentation, and the presence in the bread recipe of $0.7 \%$ (of the flour) of fat (which is usually but not always used in conventional bread recipes). This level of fat can be reduced further by the use of special blends with higher contents of fat which is solid at the dough temperature (Chamberlain, Collins \& Elton, I965 b).

One notable result of employing the CBP is that the time taken to convert the ingredients into bread is cut from about $5 \mathrm{~h}$ to about $1 \frac{3}{4} \mathrm{~h}$. Other advantages which stem from the omission of bulk dough fermentation are an extra yield of about $4 \%$ of bread and considerable saving in space. The general quality of bread produced is not impaired, and indeed in most instances, is superior to that made by conventional methods from the same flour (Chamberlain et al. 1965a).

A large-scale experiment was carried out in a commercial plant bakery by the British Baking Industries Research Association to compare the general quality of bread made by the CBP and conventionally from two grades of white flour. The results of this study will be published elsewhere. This paper presents the results of analysis of the flours and breads involved for a number of nutrients. Because of the reduction in the time of exposure to enzyme action and yeast metabolism, the higher dough temperatures and yeast levels, and the mechanical treatment of the dough in the CBP, it was decided to investigate the fate of protein, thiamine and nicotinic acid.

In addition, moisture, fat, ash and, because it was used as an improver, ascorbic acid, were determined. Carbohydrate was estimated by difference.

Possible damage to the nutritional quality of flour protein by use of the CBP was looked for in a separate experiment by baking two samples of white flour into bread 
by both processes in a pilot-scale bakery. These flours and loaves were used in the determination of net protein utilization values in feeding trials with rats.

Throughout the paper the term 'water' is used for the water measured out and used as such in making the doughs and the term 'moisture' for the natural water contents of the solid dough ingredients and the resultant breads.

\section{EXPERIMENTAL}

\section{Details of commercial bread baking}

One flour ('strong') was milled from a grist containing $60 \%$ of strong wheat and $40 \%$ of weak wheats, and the other flour grist ('weak') consisted of $35 \%$ of the same strong wheat and $65 \%$ of the same weak wheats. The flours were supplemented with chalk, iron, thiamine and nicotinic acid in accordance with The Bread and Flour Regulations, I963 (Great Britain, Parliament, 1963).

The recipes used are given in Table $\mathbf{~}$.

Table I. Recipes used in commercial-scale baking

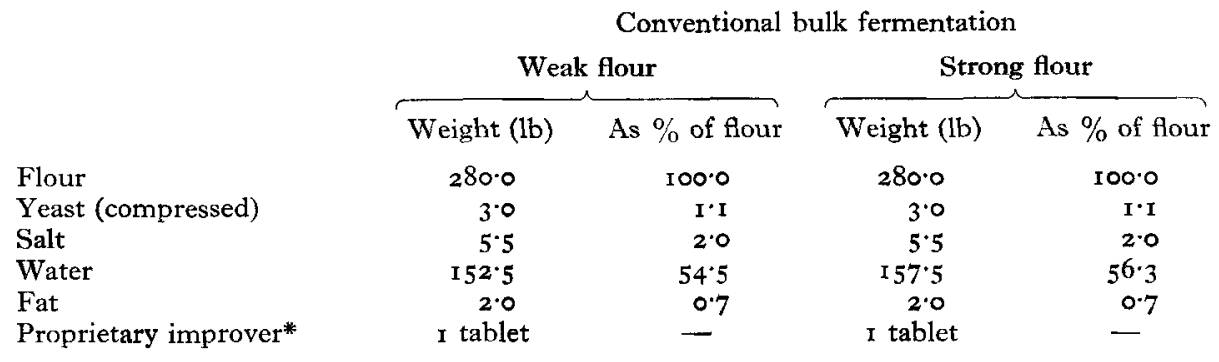

Chorleywood Bread Process

\begin{tabular}{|c|c|c|c|c|}
\hline & Wer & flour & Stro & flour \\
\hline & Weight (lb) & As $\%$ of flour & Weight (lb) & As $\%$ of flour \\
\hline Flour & $280 \cdot 0$ & $100 \cdot 0$ & $280 \cdot 0$ & $100 \cdot 0$ \\
\hline Yeast (compressed) & 6.0 & $2 \cdot I$ & 6.0 & $2 \cdot 1$ \\
\hline Salt & $5 \cdot 5$ & $2 \cdot 0$ & 5.5 & $2 \cdot 0$ \\
\hline Water & $163 \cdot 25$ & $58 \cdot 3$ & $167 \cdot 25$ & $59 \cdot 8$ \\
\hline Fat & $2 \cdot 0$ & 0.7 & $2 \cdot 0$ & 0.7 \\
\hline Proprietary improver* & I tablet & - & I tablet & - \\
\hline Ascorbic acid & $9.5 \mathrm{~g}$ & 0.0075 & $9.5 \mathrm{~g}$ & 0.0075 \\
\hline
\end{tabular}

* The proprietary improver tablets are designed to aid dough maturation and yeast activity. Each tablet weighs about $57 \mathrm{~g}$ and contains ammonium chloride, calcium sulphate, a little potassium bromate, and starch filler.

In the conventional fermentation process the dough was mixed and then set aside to ferment for $3 \mathrm{~h}$ at $27^{\circ}$. The fermented dough was divided into pieces weighing $\mathrm{I} .97 \mathrm{lb}\left(\mathrm{I} \mathrm{lb}{ }_{5} \frac{1}{2} \mathrm{oz}\right.$ ) which were given an intermediate proof of $12 \mathrm{~min}$ at $27^{\circ}$. After final moulding, the dough pieces were placed in tins and given a final proof of $52 \mathrm{~min}$ at $40^{\circ}$. Baking in a travelling oven was for $28 \mathrm{~min}$ at an average oven temperature of about $216^{\circ}$. 
In the CBP the doughs were taken immediately from the mixer, with a temperature of $30^{\circ}$, to the divider. The rest of the procedure was the same as for conventional bread except that the intermediate proof period was reduced to $9 \mathrm{~min}$.

All the bread was cooled for $3 \mathrm{~h} 20 \mathrm{~min}$ to a final internal temperature of about $27^{\circ}$ and mechanically wrapped.

The dough-handling system of this commercial bakery was such that the final pieces of moulded dough arrived consecutively on a moving belt in front of the final prover. The dough pieces were placed by hand into tins carried in rows of twenty on suspended shelves in the prover. The moving shelves then progressed through the controlled temperature and humidity of the prover, the intact rows of twenty tins finally being transferred mechanically to the moving sole of the oven. On discharge from the oven the rows of loaves were automatically separated from the tins and transferred to the moving shelves of the cooler. The cooled loaves were discharged from the cooler on to a moving belt and passed consecutively through the wrapping machine.

Two doughs, each from $280 \mathrm{lb}$ of flour, were mixed and processed into bread for each of the four combinations of flour and bread-making method. Each dough gave rise to approximately 220-230 loaves and the throughput rate of the plant was such that the dough pieces took about 6 min to pass any point in the sequence following the divider.

Samples for test were marked by affixing numbered paper labels to the middle eight dough pieces in each alternate row of twenty in the final prover. The baked loaves, with labels still adhering, were then collected from the cooler, passed through the wrapping machine and re-labelled on the outside of the opaque wrapper.

The samples were used for a variety of purposes but those referred to in this paper were selected as follows.

The fifth loaf from one end of each labelled group of eight was taken for determinations of moisture content in the whole loaf in the laboratories of the British Baking Industries Research Association. This gave a total of six loaves, taken at intervals of approximately i min from each dough, or twelve for each combination of flour and process. The samples thus represented approximately $2.5 \%$ of the total number of loaves made in that group.

The third loaf from one end of each alternate labelled group of eight was used for nutrient analysis in the Laboratory of the Government Chemist. This gave three loaves from each dough, or half the number used for determinations of moisture content.

This system of sampling ensured that in comparisons between conventional and CBP baking the loaves had been in the same relative positions in the prover and oven.

\section{Details of pilot-scale baking}

One flour ('strong') was a normal, commercial basic grade of bread flour. The second flour ('weak') was prepared by blending the strong flour with a commercial biscuit flour in the proportions 3 : I by weight.

The recipes used were the same as those for the commercial baking with the 
exceptions that the yeast level in the conventional method was $r \cdot 4 \%$ instead of $I \cdot I$, the proprietary improver tablets were not used and the water contents were $(\%$ of flour):

$\begin{array}{ll}\text { Weak flour, conventional method } & 54 \cdot 3 \\ \text { Strong flour, conventional method } & 5^{\cdot} \cdot 4 \\ \text { Weak flour, CBP } & 57^{\cdot 8} \\ \text { Strong flour, CBP } & 5^{8 \cdot 6}\end{array}$

The main details of the processing times and temperatures were the same as those for commercial baking except that the dough pieces weighed $\mathrm{r} \mathrm{lb}$ and baking was for $25 \mathrm{~min}$ at $22 \mathrm{I}^{\circ}$. Single doughs large enough to provide nine loaves were processed for each combination of flour and process, baking was in a reel oven and all the loaves were bulked together for determination of net protein utilization.

Bread Analytical methods

Moisture in whole loaf. Each whole loaf was weighed, air-dried, re-weighed and ground. Residual moisture was determined in a $4^{-6} \mathrm{~g}$ sample by drying at $103^{\circ}$ for $5 \mathrm{~h}$. With the exception of ascorbic acid, the remaining analyses were carried out on a representative sample of each loaf which had been crumbled and dried in a ventilated oven at $80^{\circ}$. Experience has shown that this procedure does not affect any of the entities subsequently determined.

Moisture in bread sample. $5 \mathrm{~g}$ was heated at $100^{\circ}$ at normal pressure for $5 \mathrm{~h}$.

Ash. Io $\mathrm{g}$ was ashed in a muffle furnace at $55^{\circ}$.

Protein. Nitrogen content was determined by the Kjeldahl method of the Fertilizers and Feeding Stuffs Regulations, 1960 (Great Britain, Parliament, 1960) used with samples of $2 \mathrm{~g}$. Protein is expressed as $\mathrm{N} \times 5.7$.

Fat. The method described by Kent-Jones \& Amos (1957) was used.

Carbohydrate. Total carbohydrate was estimated by difference. The value was then multiplied by the factor 0.97 to give the values quoted for available carbohydrate (see Fraser \& Holmes, 1956).

Ascorbic acid. ro $\mathrm{g}$ of crumbled fresh bread from a slice taken from the middle of each loaf was extracted with $100 \mathrm{ml}$ of $2 \%$ oxalic acid in oxygen-free water (Roe, 1936). The extract was cleared by centrifugation and filtration, and ascorbic acid and dehydroascorbic acid were determined as described by Pearson (1962).

Nicotinic acid. The method of Barton-Wright (1963) was used. A standard sample was included in every assay to monitor the extraction conditions.

Thiamine. The method recommended by the Sub-committee on Vitamin Estimations (Society of Public Analysts and Other Analytical Chemists: Analytical Methods Committee, I95I) was used. The stage involving isolation of the thiamine on a zeolite was omitted.

\section{Flour}

Two random samples of each of the two flours were analysed.

Moisture, ash, protein, fat, carbohydrate and nicotinic acid were determined as for bread samples. Thiamine was determined by the method of Ridyard (1949). 


\section{Determination of net protein utilization}

The NPUs were determined by the method of Miller \& Bender (I955) as modified by Miller \& Payne (196r). The bread was freeze-dried and ground in a hammer mill. Both flours and bread were supplemented with a complete vitamin and mineral mixture.

\section{RESULTS AND DISCUSSION}

The mean values for the analyses of the flours and breads are given in Tables 2 and 3. Values for ascorbic acid are not given as the results were below the level of detection $(2 \mathrm{mg} / 100 \mathrm{~g}$ ) for all samples.

\section{Table 2. Nutrient contents of flours and bread $(\%)$}

\begin{tabular}{|c|c|c|c|c|c|c|c|}
\hline \multirow[b]{2}{*}{ Nutrient } & \multicolumn{2}{|c|}{ Flour } & \multicolumn{2}{|c|}{ CBP bread } & \multicolumn{2}{|c|}{$\begin{array}{c}\text { Conventional } \\
\text { bread }\end{array}$} & \multirow{2}{*}{$\begin{array}{l}\mathrm{SE} \text { of } \\
\text { means }\end{array}$} \\
\hline & Weak & Strong & Weak & Strong & Weak & Strong & \\
\hline Moisture (g/I00 g) & I 3.9 & I $4 \cdot 5$ & 39.4 & $40 \cdot 3$ & $38 \cdot 7$ & $39^{\cdot} \mathrm{I}$ & 0.12 \\
\hline Protein $(\mathrm{g} / \mathrm{1} 00 \mathrm{~g})$ & $11 \cdot 0$ & I $2 \cdot 0$ & $7 \cdot 7$ & $8 \cdot 3$ & $7 \cdot 8$ & $8 \cdot 4$ & 0.04 \\
\hline Fat $(g / 100 \mathrm{~g})$ & I.5S & $I \cdot 56$ & $I-64$ & 1.69 & $x \cdot 65$ & $x \cdot 66$ & 0.05 \\
\hline $\operatorname{Ash}(\mathrm{g} / 100 \mathrm{~g})$ & 0.66 & 0.69 & $1 \cdot 77$ & $1 \cdot 77$ & $x \cdot 78$ & $I \cdot 80$ & 0.02 \\
\hline Carbohydrate $(\mathrm{g} / 100 \mathrm{~g})$ & $72 \cdot 9$ & $7 x \cdot 4$ & $49 \cdot 5$ & $48 \cdot 2$ & $50 \cdot I$ & $49 \cdot 1$ & 0.07 \\
\hline Thiamine (mg/roo g) & 0.31 & 0.30 & 0.20 & 0.21 & 0.18 & 0.17 & 0.007 \\
\hline Nicotinic acid (mg/roo g) & $2 \cdot 12$ & $2 \cdot 27$ & $I \cdot 62$ & $I \cdot 58$ & $I \cdot 64$ & $x \cdot 67$ & 0.05 \\
\hline
\end{tabular}

CBP, Chorleywood Bread Process.

Each value for flour is the mean of results for two samples. The bread moisture contents are the means for twelve samples, and the other nutrient contents the means for six samples.

Table 3. Nutrient contents of flours and bread ( $\%$ of dry solids) derived from Table 2

\begin{tabular}{|c|c|c|c|c|c|c|}
\hline \multirow[b]{2}{*}{ Nutrient } & \multicolumn{2}{|c|}{ Flour } & \multicolumn{2}{|c|}{ CBP bread } & \multicolumn{2}{|c|}{ Conventional bread } \\
\hline & Weak & Strong & Weak & Strong & Weak & Strong \\
\hline Protein $(\mathrm{g} / \mathrm{1} 00 \mathrm{~g})$ & I $2 \cdot 8$ & 14.0 & $12 \cdot 7$ & $13 \cdot 9$ & $12 \cdot 7$ & 13.8 \\
\hline Fat $(\mathrm{g} / \mathrm{I} 00 \mathrm{~g})$ & $I \cdot 80$ & $I \cdot 82$ & $2 \cdot 7 \mathrm{I}$ & $2 \cdot 83$ & 2.69 & $2 \cdot 73$ \\
\hline Ash (g/100 g) & 0.77 & $0.8 \mathrm{I}$ & 2.92 & $2 \cdot 96$ & $2 \cdot 90$ & $2 \cdot 96$ \\
\hline Carbohydrate (g/100 g) & 84.7 & $83 \cdot 5$ & $81 \cdot 7$ & 80.7 & $81 \cdot 7$ & 80.6 \\
\hline Thiamine $(\mathrm{mg} / \mathrm{lo0} \mathrm{g})$ & 0.36 & 0.35 & 0.33 & 0.35 & 0.29 & 0.28 \\
\hline Nicotinic acid (mg/roo g) & $2 \cdot 46$ & $2 \cdot 65$ & 2.67 & 2.65 & $2 \cdot 68$ & $2 \cdot 74$ \\
\hline
\end{tabular}

CBP, Chorleywood Bread Process.

Table 4. Standardized values for the net utilization of the protein of flours and bread (\%)

(Mean values with their standard errors)

$\begin{array}{lccc}\text { Type } & \text { Flour } & \text { CBP bread } & \text { Conventional bread } \\ \text { Weak } & \mathbf{3} \pm \pm \mathbf{3} & \mathbf{3 7 \pm 2} & \mathbf{3 7 \pm 2} \\ \text { Strong } & 38 \pm 5 & 35 \pm \mathbf{1} & \mathbf{3 7} \pm \mathbf{3}\end{array}$

CBP, Chorleywood Bread Process. 
The values of the different constituents do not always add up to exactly $100 \%$ because the moisture contents quoted were determined in a separate laboratory on different samples.

The NPU values obtained on the samples of weak and strong flours and the bread made from them are given in Table 4 .

\section{Moisture}

The differences in moisture content of the breads between (a) CBP weak and conventional strong, and $(b)$ conventional weak and conventional strong, were not significant at the $5 \%$ level of probability. The differences between all the other possible pairs of results, though small, were significant at the I \% level.

With both flours the CBP bread had a slightly higher moisture content. It is not clear why the differences between processes were not about the same for each of the flours. For example, the difference between the water content of the recipes of the CBP strong and fermented strong breads was $9.75 \mathrm{lb}$ (equivalent to a difference in water addition of $x \cdot 14 \%$ of total dough weight) and the difference in moisture content of the loaves was $\mathrm{I} \cdot \mathrm{I} 6 \%$. Between CBP weak and fermented weak the difference was I0.75 $\mathrm{lb}$ in water content of the recipes (equivalent to a difference in water addition of $1.32 \%$ of total dough weight) and yet only $0.68 \%$ in loaf moisture content.

These results suggest that some inaccuracy in water measurement when making up the doughs and variations in baking losses may have confused the picture.

\section{Nutrients}

It is clear that there were no gross differences between the two types of bread in the content of the nutrients measured.

The ascorbic acid content of all the samples was less than $2 \mathrm{mg} / \mathrm{roog}$. Other tests, with a more sensitive method (Moor, 1957), on other samples have shown that the ascorbic acid plus dehydroascorbic acid content of CBP bread is less than $0.2 \mathrm{mg} / \mathrm{I00} \mathrm{g}$. This finding confirms the almost total loss of vitamin $\mathrm{C}$ activity during baking.

Statistical analysis of the results in Table 2 confirms that the differences between the values for fat, ash and nicotinic acid in the bread were not significant at the $5 \%$ level.

The values for the composition of the dry matter of the flours and bread (Table 3) are of interest. The rise in the fat content in proceeding from flour to bread is closely accounted for by the fat added in the recipe, and the rise in the ash content by the addition of salt. The similarity of the figures for nicotinic acid in the various bread samples, despite differences of yeast content in the recipes, indicates that the contribution by yeast to the level of this vitamin in bread is negligible.

The only marked differences between protein contents of the breads are directly attributable to the difference in protein content of the flours; this also can be seen clearly in Table 3 .

All the differences between the carbohydrate contents of the various bread samples, as shown in Table 2, though small, were statistically significant at the I \% level. The 
higher content of the fermented breads is in conflict with the results of previous unpublished analytical work by the British Baking Industries Research Association, which showed a higher carbohydrate content in CBP bread. However, the differences between breads from the same flour disappear when considered on the dry-matter basis (Table 3 ).

The differences between the thiamine contents of the breads from the two processes were statistically significant at the I \% level. It might be thought at first that the higher content of the CBP bread was attributable to the extra yeast used in the recipe, but this seems unlikely. Pyke (1958) gives the thiamine content of baker's yeast as $2.0-4.0 \mathrm{mg} / \mathrm{r} 00 \mathrm{~g}$ dry matter. Assuming the high level and a yeast dry-matter content of $27 \%$, the extra $3 \mathrm{lb}$ of yeast in the CBP recipe would only account for a difference in the thiamine content of the bread of about $0.0 \mathrm{Img} / \mathrm{I} 00 \mathrm{~g}$ on a drymatter basis, whereas the actual difference was 0.04 for the bread from the weak flour and 0.07 from the strong (Table 3 ).

Adding a contribution by the yeast of $0.01 \mathrm{mg} / \mathrm{I} 00 \mathrm{~g}$ thiamine to the values for flour (Table 3) and calculating the fall in thiamine content of the dry matter in proceeding from dough to conventional bread, gives a loss of $19 \%$ for the weak flour and $23 \%$ for the strong. By comparison, Coppock, Carpenter \& Knight (1957) reported an overall average thiamine baking loss in white breads of $15 \%$. For the CBP bread the contribution by the yeast is doubled and a similar calculation gives losses of $13 \%$ for the weak flour and $6 \%$ for the strong. This seems to indicate that thiamine losses were greatest in the making of conventional bread, perhaps during the bulk fermentation of the dough. Though some workers have not found this to be so (e.g. Coppock et al. 1957), others have reported its occurrence (e.g. Iwao, Takai \& Kenmoku, 1958).

\section{Net protein utilization}

There were no significant differences between the two processes for either of the flours and the values found were within the range regarded as normal for these products.

We thank Mr R. A. Knight for the determination of the moisture contents quoted and $\mathrm{Mr}$ S. J. Cornford for statistical analysis.

\section{REFERENCES}

Barton-Wright, E. C. (1963). Practical Methods for the Microbiological Assay of the Vitamin B Complex and Amino Acids. London: United Trade Press.

Chamberlain, N., Collins, T. H. \& Elton, G. A. H. (1962). Baker's Dig. 36, 52.

Chamberlain, N., Collins, T. H. \& Elton, G. A. H. (1965a). Cereal Sci. Today 10, 412.

Chamberlain, N., Collins, T. H. \& Elton, G. A. H. (1965b). Cereal Sci. Today ro, 415.

Coppock, J. B. M., Carpenter, B. R. \& Knight, R. A. (1957). Chemy Ind. p. 735.

Fraser, J. R. \& Holmes, D. C. (1956). F. Sci. Fd Agric. 7, 589.

Great Britain, Parliament (1960). Fertilisers and Feeding Stuffs Regulations, 1960. Stat. Instrum. no. I I65. Great Britain, Parliament (1963). The Bread and Flour Regulations, 1963. Stat. Instrum. no. 1435.

Iwao, H., Takai, Y. \& Kenmoku, A. (1958). Rep. natn. Inst. Nutr., Tokyo p. 66.

Kent-Jones, D. W. \& Amos, A. J. (r957). Modern Cereal Chemistry, $5^{\text {th }}$ ed. Liverpool: The Northern Publishing Co.

Miller, D. S. \& Bender, A. E. (1955). Br. F. Nutr. 9, 382.

Miller, D. S. \& Payne, P. R. (I96r). Br. F. Nutr. r5, Ir. 
Ministry of Agriculture, Fisheries and Food: National Food Survey Committee (1965). Domestic Food Consumption and Expenditure: 1963. London: H,M. Stationery Office.

Moor, H. (1957). Fd Mf. 32, I 19.

Pearson, D. (1962). Chemical Analysis of Foods, 5 th ed. London: J. and A. Churchill.

Pyke, M. (1958). In The Chemistry and Biology of Yeasts, p. 535. [A. H. Cook, editor.] New York: Academic Press Inc.

Ridyard, H. N. (1949). Analyst, Lond. 74, I8.

Roe, J. H. (1936). F. biol. Chem. I16, 609.

Society of Public Analysts and other Analytical Chemists: Analytical Methods Committee (I95I). Analyst, Lond. 76, 127. 